\title{
OPTIMIZATION OF EXTRACTION CONDITIONS FOR ANDROGRAPHOLIDE USING FRACTIONAL FACTORIAL DESIGN
}

\author{
Mohamad Rafi ${ }^{1,2}$, Latifah Kosim Darusman ${ }^{1,2, *}$, Eulis Siti Nurasiah ${ }^{1}$, Utami Dyah \\ Syafitri $^{3}$
}

\begin{abstract}
1Biopharmaca Research Center, Bogor Agricultural University. Jl. Taman Kencana No. 3, Bogor 16128, Indonesia

2Dept. of Chemistry, Faculty of Mathematics and Natural Sciences, Bogor Agricultural University. Jl. Agatis, Bogor 16880, Indonesia ${ }^{3}$ Dept. of Statistics, Faculty of Mathematics and Natural Sciences, Bogor Agricultural University. Jl. Meranti, Bogor 16880, Indonesia
\end{abstract}

Submitted: 09-03-2014

Revised: $15-05-2014$

Accepted: $02-06-2014$

*Corresponding author Latifah Kosim Darusman

Email :

latifah.kd@gmail.com

\begin{abstract}
Andrographolide is a major bioctive compound found in king of bitter (Andrographis paniculata). In this study, the extraction method and its condition were investigated in order to get an extract with maximum amount of andrographolide by comparing three other extraction methods, i.e. maceration, soxhletation and ultrasonication and also determination for the optimum condition of the selected extraction method. The highest andrographolide amount was found by maceration, so this method was choosen for further optimization of extraction condition. The optimum condition based on the prediction amount from 27 factor combinations was obtained in 360 times of extraction time, $2 \mathrm{~g} / 100 \mathrm{~mL}$ of sample to solvent ratio, and 3fold of extraction frequency with prediction of andrographolide amount was $3.50 \%$. While by using prediction profile, the optimum condition was obtained in $360 \mathrm{~min}$ of extraction time, $2 \mathrm{~g} / 100 \mathrm{~mL}$ of sample and solvent ratio, and 4 times of extraction frequency with the amount was $3.47-3.74 \%$.
\end{abstract}

Key words: Andrographolide, king of bitter, Andrographis paniculata, fractional factorial design

\section{INTRODUCTION}

King of bitter (Andrographis paniculata Nees) is belongs to the family Acanthaceae and locally known as sambiloto. In Indonesia, sambiloto is widely used as ingredient in jamu (traditional Indonesian medicine). This plant usually used in jamu for the treatment of fever and itching in the skin, also as a tonic (BPOM, 2006). In addition, some studies show that king of bitter has a broad spectrum of biological activities such as anti-inflammatory (Shen $e t$ al., 2002; Sheeja et al., 2006), antioxidants (Sheeja et al., 2006; Trivedi and Rawal 2001) antidiarrheal (Gupta et al., 1993), antivirus (Wiart et al., 2005), antimalarial (Dua et al., 2004; Zein et al., 2013), hepatoprotective (Rana and Avadhoot, 1991; Kapil et al., 1993), anticancer (Matsuda et al., 1994; Kumar et al., 2004), antihyperglycemic (Soetarno et al., 1999; Zhang and Tan, 2000; Reyes et al., 2006), immunostimulant (Kumar $e t$ al., 2004) and antibacterial (Singha et al., 2003).

Major bioactive compound found in king of bitter are from diterpene lacton. Andrographolide (Figure 1) is known as one of the major bioactive compound present in king

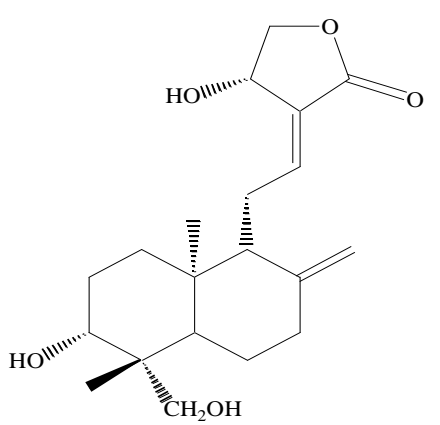

Figure 1.Chemical structure of andrographolide

of bitter (Jarukamjorn and Nemoto, 2008). Some biological activities such as antiinflammatory (Shen et al., 2000), antidiarrheal (Gupta et al., 1993), anticancer (Sheeja et al., 2007), inhibition of platelet aggregation (Amroyan et al., 1999) and hepatoprotective (Singha et al., 2007) are possesed. With these broad activities, it is necessary to have an extraction method with a maximum level of andrographolide in order to minimize the use of crude extract for a given dose based on the levels of andrographolide. Maceration, soxhletation and ultrasonication which have 
been used extensively for andrographolide extraction. Each method has its own advantages and disadvantages. Therefore, we need to choose one from those methods and find optimum conditions that can extract andrographolide as much as possible.

This study aimed to find the best extraction method wth the optimum conditions for the extraction of andrographolide from king of bitter herbs using a randomized complete design (RCD) and fractional factorial design (FFD). Three extraction method namely maceration, soxhletation and ultrasonication were evaluated. RCD was used to choose an extraction method that give the highest yield of andrographolide. Further optimization of the selected extraction method was performd by evaluating variation the sample to solvent ratio, time and frequency of the extraction using RFF to reduce the number of experiment combinations.

\section{MATERIAL AND METHODS Apparatus}

Maceration, soxhletation and ultrasonication extraction apparatus, rotary evaporator R-114 (Buchi, Switzerland), high performance liquid chromatography La Chrom Elite equipped with UV-Vis detector L-2420 (Hitachi, Japan).

\section{Material and chemicals}

King of bitter was obtained from Medicinal Plant Station of Biopharmaca Research Center, Bogor Agricultural University, Dramaga, Bogor. Dried samples were grounded to obtain 100 mesh particle size prior to be extracted. Andrographolide standard was purchased from Sigma-Aldrich (St. Louis, USA). Methanol p.a for extraction solvent and HPLC grade for the mobile phase were purchased from Merck (Darmstadt, Germany).

\section{Maceration}

Maceration method used in this study was referred to the method used by Akowuah et al. (Akowuah et al., 2006). The experiment was performed in $250 \mathrm{~mL}$ flask with $1 \mathrm{~g}$ of powdered sample in $100 \mathrm{~mL}$ methanol p.a. The extraction was carried out by soaking for $300 \mathrm{~min}$ at room temperature and stirred constantly. The filtrate obtained was concentrated using a rotary evaporator. Extraction process was repeated three times.

\section{Soxhletation}

Soxhletation method reported by Wongkittipong et al. (Wongkittipong et al., 2004) was used in this study. One gram powdered sample was soaked in $100 \mathrm{~mL}$ of methanol p.a for $210 \mathrm{~min}$ at $75^{\circ} \mathrm{C}$ and normal pressure. The filtrate obtained was concentrated using a rotary evaporator. Extraction process was performed in triplicate.

\section{Ultrasonication}

Ultrasonication method was referred to the method used by Yanfang et al. (Yanfang et al., 2006). In a $250 \mathrm{~mL}, 1 \mathrm{~g}$ powdered sample with $100 \mathrm{~mL}$ of methanol p.a. The mixture extracted for $30 \mathrm{~min}$ using an ultrasonic bath at room temperature. The filtrate allowed to stand at room temperature for $30 \mathrm{~min}$ before it was filtered. Extraction was repeated three times, after that the entire filtrate obtained was then concentrated using rotary evaporator. Triplicate extraction process was performed.

\section{Determination of andrographolide}

Andrographolide content was determined by HPLC according to the method developed by Akowuah et al 2006. Andrographolide was separated using a C18 column. Methanol-water (6:4 v/v) with $\mathrm{pH} 2.8$ adjusted with phosphoric acid, was used as the mobile phase in isocratic mode. Temperature during elution was kept at $25^{\circ} \mathrm{C}, 20 \mu \mathrm{L}$ of injection volume and the flow rate of $1 \mathrm{~mL} / \mathrm{min}$. Detection of andrographolide was performed at a wavelength of $210 \mathrm{~nm}$. An appropriate amount of standard stock solution was diluted with methanol to obtain three concentrations of the working standard solutions of the andrographolide for constructing the calibration curves. Andrographolide content was determined by using the calibration curve obtained previously.

\section{Selection and optimization of extraction conditions}

Selection of the extraction methods were evaluated using the RCD. F test is used to evaluate the effect of each factor to the 
response under hypothesis null $\left(\mathrm{H}_{0}\right)$ : all extraction methods have the same effect to the lconcentration of andrographolide. If $\mathrm{F}_{\text {observed }}$ $>\mathrm{F}_{\text {table, then }} \mathrm{H}_{0}$ is rejected, which means at least 1 extraction method affected the concentration of andrographolide. Further testing was performed in order to determine the most influential method in andrographolide content for choosing the selected extraction method. Selected extraction method obtained by RCD then optimized the conditions by evaluating the solvent ratio, extraction time, and the frequency of extraction using fractional factorial design $3^{\mathrm{k}-1}$.

\section{Data analysis}

Design experiment and data analysis was performed in SAS software version 9.1 (SAS Institute, North Carolina, USA)

\section{RESULT AND DISCUSSIONS}

\section{Selection of extraction method}

Three extraction methods were used namely maceration, soxhletation and ultrasonication to extract andrographolide. Differences from the three methods involved in the process of energy for extraction. Yield from maceration, soxhletation and ultrasonication methods are 33.3\%, 30.8\%, and $30.4 \%$ with andrographolide content are $2.83 \%$, $2.23 \%$ and $1.86 \%$, respectively. Extraction by maceration give the highest yield compared to the other extraction methods. This result indicated that the compounds in king of bitter are not resistant to heat or easy to decompose when exposed by ultrasonic waves. Other reason because andrographolide has a lactone ring making easyly to decompose if exposed to heating or ultrasonic waves.

RCD was used for selection an appropriate andrographolide extraction method which will be continued for further optimization of the extraction conditions with FFD. RCD is one factor experimental design with keep other factors in fixed condition. Application of one factor in the RCD usually used if the experimental conditions units are relatively homogeneous. It is generally used for the experiments conducted in the laboratory because the homogeneity of experimental units used can be guaranteed. Randomization was performed directly on the experimental units (Mattjik and Sumertajaya, 2002). From the results of data analysis using RCD showed coefficient of variance of the data was 4.71\% showing that the experimental units used were relatively homogeneous. Futhermore, the three methods gave different mean value of andrographolide content at 95\% significance level becausethe $F_{\text {observed }}$ (60.62) greater than $F_{\text {table }}$ (5.14). To determine the effect of extraction method on andrographolide rendemend, Tukey test was performed another statistical test. This test was carried out by comparing all combination units on the error level of $\alpha$ with a relatively small number of combination units. The Tukey test results indicate that the three methods significantly different at the 95\% significance level. Therefore, based on the results obtained, extraction using maceration method is a safe and simple technique to extract andrographolide in the optimum manner. In addition, we choosed the maceration method also due to the highly reactive and susceptible to rearrangement of the lactone ring.

\section{Optimization of extraction conditions of maceration method}

FFD was used for optimization of the conditions for maceration extraction of andrographolide. FFD is a derivative from the factorial design with reducing the number of combination trial. FFD will be obtained through a combination that only attributed for measuring the main effects while interaction from others are ignored. FFD will give the main characters needed to represent each factor. Each level of an attribute will be combined at each level of all factors with the amount or requency are proportional (Montgomerry, 2001). Extraction conditions such as the sample to solvent ratio, extraction time and the frequency were optimized using FFD $3 \mathrm{k}^{-1}$ which only performed one third of complete combinations (Table I). Early stage of optimization was determined the correlation between the yield of extract and andrographolide content. Based on statistical test for correlation, if $\mathrm{p}$ value $<\alpha$, there is a correlation between yield extracts with andrographolide content. Otherwise, there is no evidence to say any correlation between those two variables. As the $\mathrm{p}$ value $=0.595$ was greater $\alpha=0.05$, indicating 
Table I. Fractional factorial design with $3^{k-1}$ and the experimental result

\begin{tabular}{|c|c|c|c|c|c|c|c|c|}
\hline $\begin{array}{l}\text { Obser- } \\
\text { vation }\end{array}$ & $\begin{array}{l}\text { Extrac- } \\
\text { tion time } \\
\text { (min) }\end{array}$ & $\begin{array}{l}\text { Frequen- } \\
\text { cy of } \\
\text { extraction }\end{array}$ & $\begin{array}{c}\text { Replicat } \\
\text { e } \\
\text { number }\end{array}$ & $\begin{array}{c}\text { Weight } \\
\text { of } \\
\text { sample } \\
(\mathrm{g})\end{array}$ & $\begin{array}{c}\text { Weight } \\
\text { of } \\
\text { extract } \\
(\mathrm{g})\end{array}$ & $\begin{array}{l}\text { Sample to } \\
\text { solvent } \\
\text { ratio } \\
(\mathrm{g} / 100 \mathrm{~mL})\end{array}$ & $\begin{array}{c}\text { Androgra- } \\
\text { pholide } \\
\text { content } \\
(\%)\end{array}$ & $\begin{array}{c}\text { Yield } \\
(\%)\end{array}$ \\
\hline \multirow{2}{*}{1} & \multirow{2}{*}{240} & \multirow{2}{*}{1} & 1 & 0.5001 & 0.1914 & 0.5 & 2.21 & 40.96 \\
\hline & & & 2 & 0.5001 & 0.1869 & 0.5 & 2.51 & 40.00 \\
\hline \multirow{2}{*}{2} & \multirow{2}{*}{300} & \multirow{2}{*}{5} & 1 & 0.5001 & 0.2221 & 0.5 & 2.38 & 47.53 \\
\hline & & & 2 & 0.5003 & 0.2094 & 0.5 & 2.12 & 44.8 \\
\hline \multirow{2}{*}{3} & \multirow{2}{*}{360} & \multirow{2}{*}{3} & 1 & 0.5003 & 0.2196 & 0.5 & 3.02 & 46.98 \\
\hline & & & 2 & 0.5006 & 0.2172 & 0.5 & 2.91 & 46.44 \\
\hline \multirow{2}{*}{4} & \multirow[b]{2}{*}{240} & \multirow{2}{*}{5} & 1 & 1.0005 & 0.2990 & 1.0 & 2.46 & 31.99 \\
\hline & & & 2 & 1.0013 & 0.3042 & 1.0 & 2.63 & 32.52 \\
\hline \multirow{2}{*}{5} & \multirow{2}{*}{300} & \multirow{2}{*}{3} & 1 & 1.0007 & 0.3131 & 1.0 & 2.86 & 33.49 \\
\hline & & & 2 & 1.0003 & 0.3419 & 1.0 & 2.95 & 36.58 \\
\hline \multirow{2}{*}{6} & \multirow{2}{*}{360} & \multirow{2}{*}{1} & 1 & 1.0082 & 0.2360 & 1.0 & 2.57 & 25.05 \\
\hline & & & 2 & 1.0024 & 0.2527 & 1.0 & 2.74 & 26.98 \\
\hline \multirow{2}{*}{7} & \multirow{2}{*}{240} & \multirow[b]{2}{*}{3} & 1 & 2.0007 & 0.5300 & 2.0 & 3.27 & 28.35 \\
\hline & & & 2 & 2.0001 & 0.5977 & 2.0 & 3.25 & 31.98 \\
\hline \multirow{2}{*}{8} & \multirow{2}{*}{300} & \multirow[b]{2}{*}{1} & 1 & 2.0008 & 0.4068 & 2.0 & 2.61 & 21.76 \\
\hline & & & 2 & 2.0027 & 0.3518 & 2.0 & 2.48 & 18.80 \\
\hline \multirow{2}{*}{9} & \multirow{2}{*}{360} & \multirow{2}{*}{5} & 1 & 2.0002 & 0.5839 & 2.0 & 3.48 & 31.24 \\
\hline & & & 2 & 2.0007 & 0.5763 & 2.0 & 3.54 & 30.83 \\
\hline
\end{tabular}

Table II. Estimation of coefficient regression

\begin{tabular}{lrcrc}
\hline \multicolumn{1}{c}{ Sources of variance } & Estimation & Standard error & $\mathbf{t}$ & p-value \\
\hline Intercept & 1.7472 & 0.1818 & 9.61 & $<.0001^{*}$ \\
Time & 0.0021 & 0.0005 & 4.05 & $0.0016^{*}$ \\
Frequency & 0.0620 & 0.0160 & 3.86 & $0.0022^{*}$ \\
Sample to solvent ratio & 0.3890 & 0.0420 & 9.25 & $<.0001^{*}$ \\
(Frequency-3)*(Frequency-3) & -0.0997 & 0.0139 & -7.17 & $<.0001^{*}$ \\
(Frequency-3)*(Sample to solvent ratio-1,16667) & 0.1779 & 0.0259 & 6.84 & $<.0001^{*}$ \\
\hline
\end{tabular}

*significant at $\alpha=0.05$

no evidence any correlation between the yield of the extract and andrographolide.

The next step is to build a regression analysis using stepwise method for selecting main factors and interaction factors which most influence to the response (Table II). Time and the sample to solvent ratio were linier to andrographolide content, whereas frequency give quadratic effect on the level of andrographolide. There are significant interactions between frequency and sample to solvent ratio on the andrographolide content.

The goodness of a model could be determined from the coefficient determination
$\left(\mathrm{R}^{2}\right)$. Ideally, a model is good if the value of $\mathrm{R}^{2}$ near to $100 \%$. In this study, the model has a $\mathrm{R}^{2}$ about $94.91 \%$ which means that the model approximately the variance of andrographolide about $94.91 \%$ and only $5.19 \%$ explained by other factors.

Another approach for evaluation the goodness of the model is using the coefficient of variance. If the experiments conducted in the laboratory, the coefficient of variance for a good regression model must less than 10\%. Coefficient of variance was calculated based on the ratio between the error divided by the mean response and then multiplied by $100 \%$. 
Table II. Estimation of coefficient regression

\begin{tabular}{lrcrc}
\hline \multicolumn{1}{c}{ Sources of variance } & Estimation & Standard error & $\mathbf{t}$ & $\mathrm{p}$-value \\
\hline Intercept & 1.7472 & 0.1818 & 9.61 & $<.0001^{*}$ \\
Time & 0.0021 & 0.0005 & 4.05 & $0.0016^{*}$ \\
Frequency & 0.0620 & 0.0160 & 3.86 & $0.0022^{*}$ \\
Sample to solvent ratio & 0.3890 & 0.0420 & 9.25 & $<.0001^{*}$ \\
(Frequency-3)*(Frequency-3) & -0.0997 & 0.0139 & -7.17 & $<.0001^{*}$ \\
(Frequency-3)*(Sample to solvent ratio-1,16667) & 0.1779 & 0.0259 & 6.84 & $<.0001^{*}$ \\
\hline
\end{tabular}

*significant at $\alpha=0.05$

Table III. Prediction on andrographolide content based on experiment which were not conducted

\begin{tabular}{|c|c|c|c|}
\hline $\begin{array}{l}\text { Sample to solvent ratio } \\
(\mathrm{g} / 100 \mathrm{~mL})\end{array}$ & Time (minute) & $\begin{array}{c}\text { Frequency of } \\
\text { extraction }\end{array}$ & Content* $(\% \mathrm{~b} / \mathrm{b})$ \\
\hline 0.5 & 240 & 3 & 2.65 \\
\hline 0.5 & 240 & 5 & 2.14 \\
\hline 0.5 & 300 & 1 & 2.50 \\
\hline 0.5 & 300 & 3 & 2.78 \\
\hline 0.5 & 360 & 1 & 2.63 \\
\hline 0.5 & 360 & 5 & 2.40 \\
\hline 1 & 240 & 1 & 2.38 \\
\hline 1 & 240 & 3 & 2.85 \\
\hline 1 & 300 & 1 & 2.51 \\
\hline 1 & 300 & 5 & 2.64 \\
\hline 1 & 360 & 3 & 3.11 \\
\hline 1 & 360 & 5 & 2.78 \\
\hline 2 & 240 & 1 & 2.42 \\
\hline 2 & 240 & 5 & 3.26 \\
\hline 2 & 300 & 3 & 3.37 \\
\hline 2 & 300 & 5 & 3.39 \\
\hline 2 & 360 & 1 & 2.68 \\
\hline 2 & 360 & 3 & 3.50 \\
\hline
\end{tabular}

*Obtained from regression model.

Error for this model was 0.11 and the mean content of andrographolide was $2.78 \%$, so the coefficient of variance of the model was $4 \%$.

Interaction effect between the sample to solvent ratio and frequency on andrographolide content is shown in figure 2. There are two sub-graphs in the figure, the left side in the first row is the effect of each frequency among the different levels of sample to solvent ratio. In this graph, the $\mathrm{x}$-axis is sample to solvent ratio and the $y$-axis is andrographolide content mean. The effect of andrographolide content mean among the sample to solvent ratio is different between frequency 1 and frequency 5 .
The effect is flat when frequency is 1 and on the contrary, the effect of sample to solvent ratio in frequency 5 is linear.

The graph in the second row is different way to show the interaction effect between frequency and the sample to solvent ratio. The graph shows the effect of frequency to andrographolide content in various sample to solvent ratio. The quadratic effect of frequency to the response for solvent ratio 2 is different from the the quadratic effect for solvent ratio 0.5. When the solvent ratio equal to 2 , maximum response was achieved when frequency is 4 . Viceversa, when the solvent ratio equal to 0.5 , maximum response was 


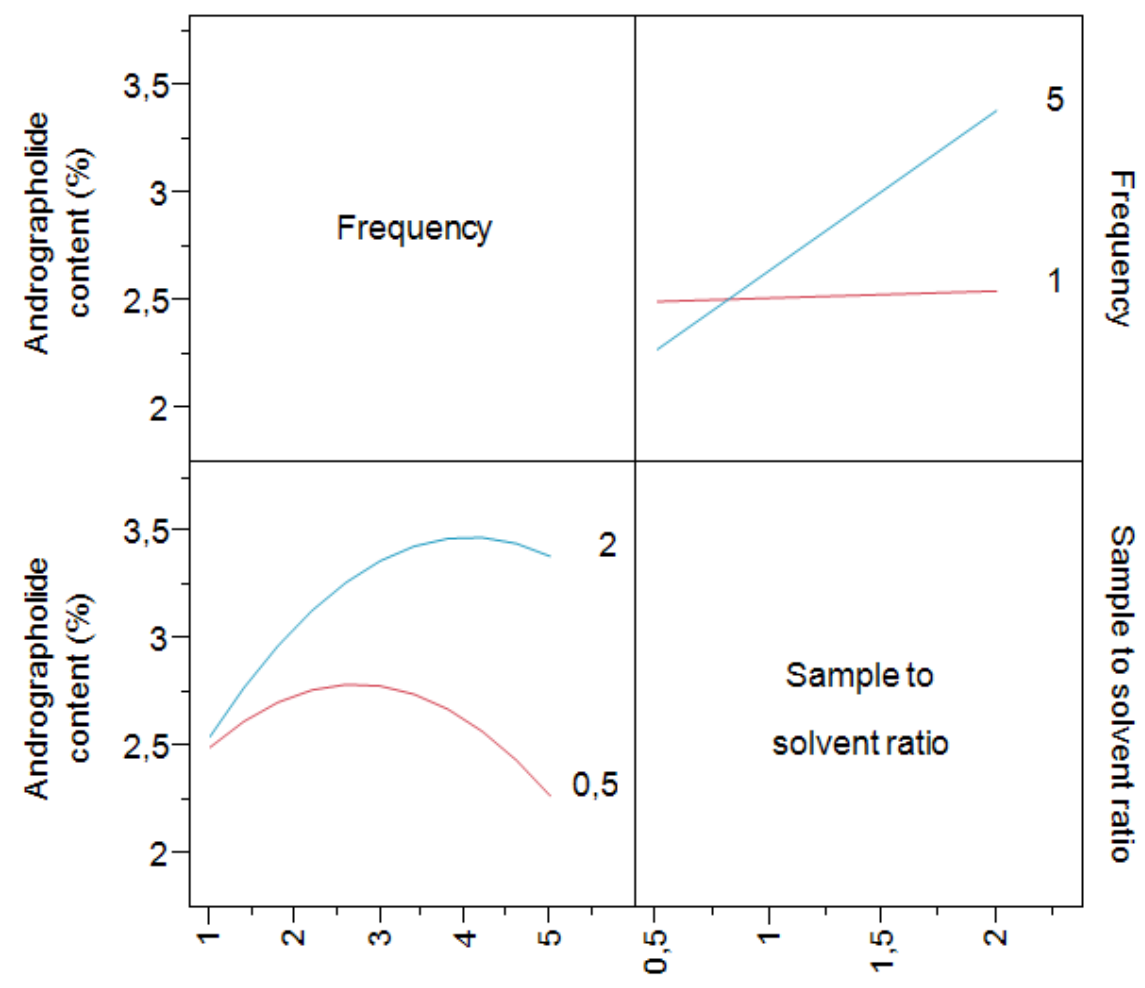

Figure 2. Plot of interactions effects of sample to solvent ratio and frequency to andrographolide content.

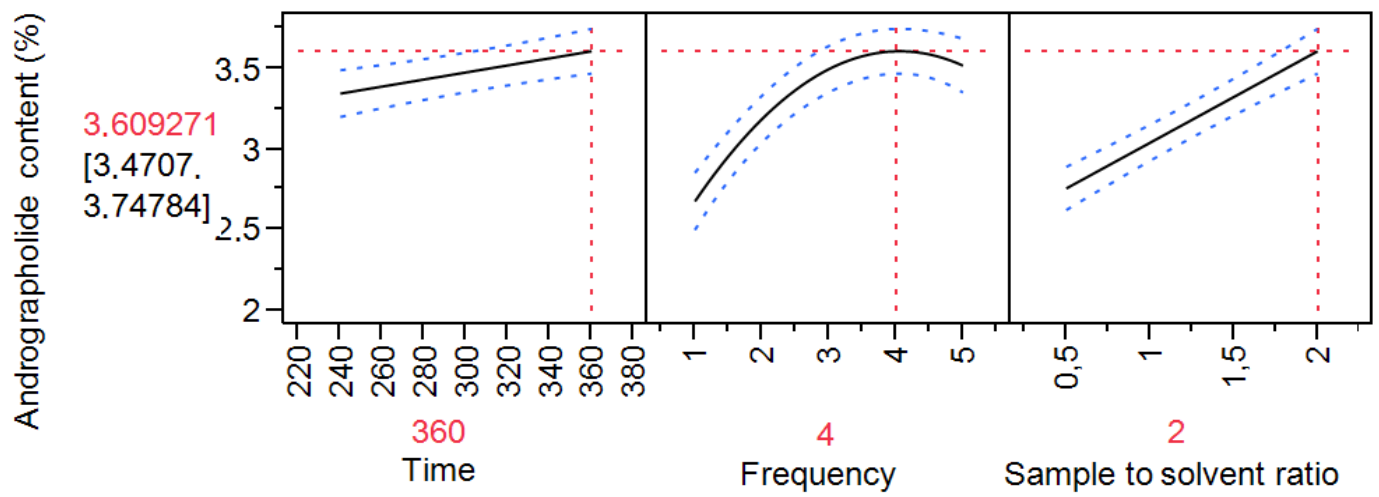

Figure 3. Prediction profile based on regression model

reached when frequency is 3 but was not as higher as when the solvent ratio $=2$ was used.

Relationship between the sample to solvent ratio, time and frequency are shown by a prediction profiles (Figure 3). Prediction profiles showed the response prediction of a certain level of each factor based on the regression model was obtained. The figure contains three sub-figures which each sub- figure shows the relationship between each factor (x-axis) and the response (y-axis). The relationship between time and sample to solvent ratio to the response were linear, respectively. Meanwhile the relationship between frequency and the response was quadratic. The optimum condition was achieved with a sample to solvent ratio 2, extraction time $360 \mathrm{~min}$ and frequency of 4 with 
the andrographolide content ranging between 3.47-3.74\%.

Furthermore, the response of other observation were predicted by regression model. Table 3 shows the prediction of of andrographolide from the combinations which are not conducted. The highest of andrographolide content $(3.5 \%)$ was achieved with sample to solvent ratio 2 , extraction time 360 minutes and frequency of extraction 3 times. Estimation under this conditions apparently give slightly lower andrographolide content when compared with the optimum conditions that estimated by prediction profiles.

Our finding showed a greater different andrographolide content compared to the result found by Mohan et al. (2013), maybe because we used a different type of extraction method. It is difficult to choose which one much better because we used sample from different location that will affect on the chemical composition of the sample. Nevertheless this finding could be used as an alternative method for extraction of andrographolide because of easy to perform and gave significant yield of andrographolide.

\section{CONCLUSION}

Androgapholide content extracted by maceration, soxhletation and ultrasonication are $2.83,2.23$ and $1.86 \%$, respectively. Maceration method was selected to optimize the extraction conditions. Optimization conditions for maceration method showed sample to solvent ration and extraction time give a linear effect, whereas frequency give a quadratic effect on the andrographolide content. The optimum extraction conditions of andrographolide content based on 27 combinations, with the sample to solvent ratio $2 \mathrm{~g} / 100 \mathrm{~mL}$, extraction time 360 minutes and frequency extraction 3 times give andrographolide content about $3.50 \%$. While using the optimum extraction conditions from prediction profiles, using sample to solvent ratio $2 \mathrm{~g} / 100 \mathrm{~mL}$, extraction time $360 \mathrm{~min}$ and frequency 4 the andrographolide content ranged between $3.47-3.74 \%$.

\section{ACKNOWLEDGEMENT}

\footnotetext{
The authors wish to thank ${ }^{1}$ Biopharmaca Research Center, Bogor Agricultural, for supporting research work.
}

\section{REFERENCES}

Badan Pengawas Obat dan Makanan Republik Indonesia (BPOM-RI), 2006, Serial Data Terkini Tumbuban Obat: Sambiloto. Andrographis paniculata (Burm. F.) Ness, Jakarta: BPOM RI.

Shen YC., Chen CF., Chiou WF., 2002, Andrographolide prevents oxygen radical production by human neutrophils: possible mechanism(s) involved in its antiinflamma-tory effect, Br. J. Pharmacol, 135, 399-406.

Sheeja K., Shihab PK., Kuttan G., 2006, Antioxidant and anti-inflammatory activities of the plant Andrographis paniculata Nees, Immunopharmacol. Immunotoxicol., 28,129-140.

Trivedi NP., Rawal UM., 2001, Hepatoprotective and antioxidant property of Andrographis paniculata (Nees) in BHC induced liver damage in mice, Ind J. Exp. Biol., 39, 41-46.

Gupta S., Yadava JNS., Tandon JS., 1993, Antisecretory (antidiarrhoeal) activity of Indian medicinal plants against Escherichia coli enterotoxin-induced secretion in rabbit and guinea pig ileal loop models, Pharm. Biol., 31, 198-204.

Wiart C., Kumar K., Yusof MY., Hamimah H., Fauzi ZM., et al., 2005, Antiviral properties of ent-labdane diterpenes of Andrographis paniculata Nees. inhibitors of herpes simplex virus type I, Phytother. Res., 19, 1069-1070.

Dua VK., Ojha VP., Roy R., Joshi BC., Valecha N., et al., 2004, Anti-malarial activity of some xanthones isolated from the roots of Andrographis paniculata, J. Ethnopharmacol., 95, 247-251

Zein U., Fitri LE., Saragih, A., 2013, Comparative study of antimalarial effect of sambiloto (Andrographis paniculata) extract. chloroquine and artemisinin and their combination against Plasmodium falciparum in-vitro, Acta Med. Indones., 45, 38-43.

Rana AC., Avadhoot Y., 1991, Hepatoprotective effects of Andrographis paniculata against carbon tetrachlorideinduced liver damage, Arch. Pharm. Res., 14, 93-95. 
Kapil A., Koul IB., Banerjee SK., Gupta BD., 1993, Antihepatotoxic effects of major diterpenoid constituents of Andrographis paniculata, Biochem. Pharmacol., 46, 182185.

Matsuda T., Kuroyanagi M., Sugiyama S., Umehara, K., Ueno A., and Nishi K., 1994, Cell differentiation-inducing diterpenes from Andrographis paniculata Nees, Chem. Pharm. Bull., 42,1216-1225.

Kumar RA., Sridevi K., Kumar NV., Nanduri S., and Rajagopal, S., 2004, Anticancer and immunostimulatory compounds from Andrographis paniculata, J. Ethnopharmacol., 92, 291-295.

Zhang XF., and Tan BK., 2000, Antidiabetic property of ethanolic extract of Andrographis paniculata in streptozotocin diabetic rats, Acta Pharmacol. Sin., 21,1157-1164.

Reyes BA., Bautista ND., Tanquilut NC., Anunciado RV., et al., 2006, Antidiabetic potentials of Momordica charantia and Andrographis paniculata and their effects on estrous cyclicity of alloxaninduced diabetic rats, J. Ethnopharmacol., 105,196-200.

Soetarno S., Sukandar EY., Sukrasno, and Yuwono A, 1999, Aktivitas hipoglisemik ekstrak herba sambiloto (Andrographis paniculata Ness. Acanthaceae), J. Mat. Sains, 4, 62-69.

Singha PK., Roy S., and Dey S., 2003, Antimicrobial activity of Andrographis paniculata, J. Ethnopharmacol., 74, 692-694.

Jarukamjorn K., Nemoto N., 2008, Pharmacological aspects of Andrographis paniculata on health and its major diterpenoid constituent andrographolide, J. Health Sci., 54, 370-381.

Shen YC., Chen CF., and Chiou WF., 2000, Suppression of rat neutrophil reactive oxygen species production and adhesion by the diterpenoid lactone andrographolide, Planta Med., 66, 314-317.

Sheeja K., Guruvayoorappan C., and Kuttan, G., 2007, Antiangiogenic activity of Andrographis paniculata extract and andrographolide, Intl. Immunopharmacol., 7, 211-221.

Amroyan E., Gabrielian E., Panossian A., Wikman, G., and Wagner H., 1999, Inhibitory effect of andrographolide from Andrographis paniculata on PAFinduced platelet aggregation, Phytomedicine, 6, 27-31.

Singha, P.K., Roy, S., and Dey, S., 2007, Protective activity of andrographolide and arabinogalactan proteins from Andrographis paniculata Nees against ethanol-induced toxicity in mice, $J$. Ethnopharmacol., 111, 13-21.

Akowuoh GA., Zhari I., Norhayati I., and Mariam A., 2006, HPLC and HPTLC densitometric determination of andrographolides and antioxidant potential of Andrographis paniculata, J. Food Compos. Anal., 19,118-126.

Wongkittipong, R., Plat, L., Damlonglerd, S., and Gourdon, C., 2004, Solid-liquid extraction of andrographolide from plants-experimental study, kinetic reaction and model, Sep. Purif. Technol., 40,147-154.

Yanfang Z., Xingping L., Zongde Z., Liren C., and Yongmin L., 2006, Simultaneous determination of andrographolide and dehydroandrographolide in Andrographis paniculata and Chinese medicinal preparations by microemulsion electrokinetic chromatography, J. Pharm. Biomed. Anal., 40,157-161.

Matjik AA., and Sumertajaya, I.M., 2002, Perancangan Percobaan dengan Aplikasi SAS dan Minitab Vol I Ed ke-2, Bogor: IPB Press.

Montgomery DC., 2001, Design and Analysis of Experimental Ed ke-5, New York: John Wiley \& Sons.

Mohan M., Khanam S., Shivananda B., 2013, Optimization of microwave assisted extraction of andrographolide from Andrographis paniculata and its comparison with refluxation extraction method, J. Pharmacog. Phytochem., 2, 342-348. 